\title{
A Green Approach for Extraction of Ammonium Molybdate from Molybdenite Using Indigenous Resources
}

\author{
Muhammad Pervaiz ${ }^{1,3 * *}$, Asima Munawar ${ }^{1}$, Shabbir Hussain ${ }^{2}$, Zohaib Saeed ${ }^{1}$, \\ Shahid Hussain ${ }^{3}$, Umer Younas ${ }^{3}$, Faisal Ali ${ }^{3}$, Asma Zaidi ${ }^{4}$, Syed Majid Bukhari ${ }^{4}$, \\ Munawar Iqbal', Ayoub Rashid ${ }^{4}$, Ahmad Adnan ${ }^{4}$, Arif Nazir ${ }^{3 *}$ \\ ${ }^{1}$ Department of Chemistry, Government College University, Lahore, Pakistan \\ ${ }^{2}$ Department of Chemistry, Lahore Garrison University Lahore, Pakistan \\ ${ }^{3}$ Department of Chemistry, The University of Lahore, Lahore, Pakistan \\ ${ }^{4}$ Department of Chemistry, COMSATS University Islamabad, Abbottabad Campus, Pakistan
}

Received: 13 May 2020

Accepted: 17 June 2020

\begin{abstract}
Present work reports on the microwave assisted extraction of molybdenum in the form of ammonium molybdate from molybdenum concentrate. In this processing, the ore was heated in air at $750^{\circ} \mathrm{C}$. The process converted the molybdenum sulphides to its oxides and evolved $\mathrm{SO}_{2}$. Molybdenum oxides were then converted into sodium molybdate which was further changed into calcium molybdate and finally ammonium molybdate using different processes. Hence, the process proved to be efficient and economical for the extraction of high quantity of molybdenum as ammonium molybdate from molybdenum ore. The spectroscopic analysis data revealed that the molybdenite contains $31.2 \%$ molybdenum from which $26 \%$ have been extracted in the form of ammonium molybdate. The project is also very valuable because the extraction process is very simple and cost effective as compared to the previously reported processes.
\end{abstract}

Keywords: molybdenite ore, microwave, UV/Vis spectroscopy, extraction

\section{Introduction}

Molybdenum is a strategic metal which is widely used in thermocouples, fabrication of radios, and in anticathode of X-rays. It is also used to produce special steel alloys. Molybdenum is an element having

\footnotetext{
*e-mail: malikanphd2013@yahoo.com
}

**e-mail: mpbhatti786@gmail.com industrial importance due to their applications in many technological fields [1-4]. There is a huge demand for molybdenum due to its various applications.

Molybdenum and sulphur combine to form of a mineral commonly known as molybdenite $\left(\mathrm{MoS}_{2}\right)$ that is the main commercial source to produce molybdenum. Molybdenite is found in the igneous rocks present deep under the earth crust near the hot magma. Molybdenum is also found in some other minerals such as wulfenite $\left(\mathrm{PbMoO}_{4}\right)$ which is yellow-red to yellow orange 
in color and powellite $\left(\mathrm{CaMoO}_{4}\right)$; greenish brown, yellow and sometimes grey in color. It is estimated that more than $90 \%$ of molybdenum, produced now a day is from mineral molybdenite [5-7]. The commercial route for molybdenum extraction involves the roasting, purification and reduction of molybdenite, but this route is associated with the production of large amount of $\mathrm{SO}_{2}$ that poses a serious environmental threat.

Moreover, pyrochemical processes needs high grade concentrate and they are not useful for the extraction of molybdenum from low grade molybdenite because it forms molybdates of impure elements which renders the processing difficult [8-11]. Extraction of molybdenum from low grade molybdenite concentrates without the emission of $\mathrm{SO}_{2}$ has therefore received much attention in recent years. From low grade concentrates, selective extraction of molybdenum has been carried out by leaching with $\mathrm{HNO}_{3}, \mathrm{NaOCl}$ solution, $\mathrm{NaOH}$ and using chlorination in the presence of oxygen [12-16]. Leaching with cyanide containing solution or by $\mathrm{FeCl}_{3}$ solution has been used especially for the removal of impurities from low grade concentrates. The roasting process has also been modified for low grade molybdenite concentrate and is carried out in the presence of soda ash or lime. High quantity of various metals like Ni, Al, $\mathrm{U}, \mathrm{W}, \mathrm{V}, \mathrm{Re}, \mathrm{Co}$ and $\mathrm{Cu}$ are also present in molybdenum resources [17-21].

Due to strict environmental regulations, electro oxidation has become one of the best routes or an alternative method for the roasting process. In electro oxidation method, $\mathrm{MoS}_{2}$ is oxidized in the electrolysis bath with solution of $\mathrm{NaOCl}$ to yield aqueous solution containing molybdenum. Several researchers have studied the extraction of molybdenum from this aqueous solution using several methods, including ion exchange, supported liquid membrane, solvent extraction and precipitation [22-24].

Herein, we report on the development/modification of a process for the extraction of pure molybdenum salt from $\mathrm{MoS}_{2}$ that is more economical and efficient. Moreover, this method yielded $99 \%$ of molybdenum in the form of molybdate of different metals that were present in $\mathrm{MoS}_{2}$.

\section{Materials and Method}

The mineral molybdenite was obtained from Azad Kashmir. The chemical constituents of the mineral are molybdenum (31.21\%), Sulphur (23.24\%), copper $(0.31 \%)$, iron $(1.60 \%)$, nickel $(0.16 \%)$, rhenium $(0.02 \%)$ and silicon $(7.40 \%)$. Distilled water, hydrochloric acid, sulphuric acid, magnesium chloride, barium chloride, ferrous chloride, nitric acid, sodium nitrate, sodium carbonate, sodium hypochlorite, isobutyl alcohol, ammonium thiocyanate, sodium thiocyanate, potassium thiocyanate, diethyl ether, yellow ammonium sulphide were purchased from Sigma-Aldrich (USA). All the chemicals were of analytical grade and used as such without further purification. FTIR spectroscopy of the products was carried out on a Frontier Optica FTIR instrument (Perkin Elmer, USA) in the spectral range of 4000-400 $\mathrm{cm}^{-1}$ with a resolution of $4 \mathrm{~cm}^{-1}$. The extraction process for the extraction of ammonium molybdate and other salts of molybdenum from the mineral molybdenite involves the following steps.

\section{Crushing of the Ore}

The treatment of molybdenum ore such as molybdenite with sodium compounds, the sulphur present in the ore was converted in to insoluble sulphur which form a layer or envelop on the surface of molybdenite ore. This covering retarded or completely prevented the reaction. To overcome, it was necessary to grind and crush the molybdenite to a fine powder. The molybdenite ore was crushed in the mortar and pestle to a mesh size of about 80-100. The fine crushing leads to better results. Finely grounded ore leads to better fusion with sodium compounds (like sodium carbonate, sodium hydroxide). The finely divided powder has large surface area and so there are greater chances for molybdenum to have fusion with sodium compounds.

\section{Roasting}

The finely powdered molybdenite ore was then roasted, prior to roasting the pulverized ore was mixed with certain sodium compounds e.g. sodium carbonate, sodium hydroxide, sodium nitrate etc. After thorough mixing of pulverized molybdenite and sodium compounds, it was placed in a furnace for about two hours. In each case the temperature range should be such that is necessary to promote the reaction. In the case of sodium nitrate the temperature was above the melting point of sodium nitrate similarly for sodium hydroxide and sodium carbonate the temperature was above the melting points of these salts. The charge was intermittently agitated as to expose it to fresh supply of oxygen during the roasting process, which was very essential for the reaction [25]. The start of the reaction was indicated by the red glow, because the reaction was highly exothermic. After roasting the mass was cooled down for further processing.

\section{Hydrometallurgical Treatment}

The mass that was roasted after cooling was subjected to hydrometallurgical treatment that involves leaching with water for about two hours under stirring conditions at high temperature. During roasting the molybdenum sulphide was converted into molybdenum oxide (oxidation of molybdenum) and in the presence of certain sodium compound, it was converted into sodium molybdate $\left(\mathrm{NaMoO}_{4}\right)$. Sodium molybdate is a water-soluble compound, in this way during leaching it goes in the water leaving behind the solid matter. 
Table 1. Characteristic IR absorption frequencies of Ammonium Molybdate.

\begin{tabular}{|c|c|c|c|}
\hline \multirow{2}{*}{ Compound } & Types of vibration & Observed value $\left(\mathrm{cm}^{-1}\right)$ for NH & Observed value $\left(\mathrm{cm}^{-1}\right)$ for OH \\
\hline \multirow{2}{*}{$\left(\mathrm{NH}_{4}\right)_{2} \mathrm{MoO}_{4}$} & Bending & 1600 & 1400 \\
\cline { 2 - 4 } & Stretching & 3395 & 3600 \\
\hline
\end{tabular}

After leaching this molybdenum solution is filtered off leaving behind the solid impurities [26].

\section{Neutralization with Magnesium Chloride}

Magnesium chloride in aqueous solution was added to the solution of molybdenum (sodium molybdate solution), along with constant stirring and heating until the molybdenum solution became almost neutral. Alternatively, magnesium chloride can be replaced with other neutralizing agents such as nitric acid. Magnesium chloride is preferably used as a neutralizing agent because one of its main functions is the formation of insoluble magnesium compounds of phosphorous and arsenic. Then these insoluble compounds can be filtered off. So, in this way we can eliminate impurities from the molybdenum solution. In this way we obtained the pure molybdenum solution in the form of sodium molybdate.

Calcium, iron and other water-soluble chloride are added to the molybdenum solution that was free from the precipitates of magnesium. The molybdenum solution was heated up to the boiling temperature and constantly stirred until all the molybdenum that was present in the solution was precipitated as iron, calcium and other molybdates. The molybdates that were formed were filtered out. The collected precipitate was then washed with warm water to eliminate impurities.

\section{Formation of Calcium Molybdate}

Calcium chloride was added to the molybdenum solution that was free from the precipitates of magnesium. The molybdenum solution was heated up to the boiling temperature and constantly stirred until all the molybdenum that was present in the solution was precipitated calcium molybdate. The calcium molybdate that was formed filtered out. The collected precipitate was then washed with warm water to eliminate impurities.

\section{Formation of Ammonium Molybdate}

The precipitates of calcium molybdate were then dried and refluxed for two hours with aqueous solution of ammonia to get ammonium molybdate. After that, the precipitates of molybdenum were collected, dried, and identified by FT-IR and UV/Vis spectrophotometer.

\section{Results and Discussion}

The IR spectra were recorded in the range of 4000-400 $\mathrm{cm}^{-1}$ as $\mathrm{KBr}$ pallets. The IR spectra of ammonium molybdate exhibited the bending vibrations due to $\mathrm{NH}$ and $\mathrm{OH}$ groups at $1600 \mathrm{~cm}^{-1}$ and $1400 \mathrm{~cm}^{-1}$ respectively. Similarly, the stretching vibrations of $\mathrm{O}-\mathrm{H}$ and N-H groups were observed at $3600 \mathrm{~cm}^{-1}$ and $3395 \mathrm{~cm}^{-1}$ correspondingly. The broad bands for $\mathrm{N}-\mathrm{H}$ stretch and $\mathrm{O}-\mathrm{H}$ stretch indicate the presence of hydrogen bonding. Otherwise, the sharp bands would have appeared. Table shows the FTIR results for stretching and bending vibrations.

In the presence of $\mathrm{HCl}$ colored complex (orangeyellow) was formed by adding thiocyanate in the solution of molybdenum. Isobutyl alcohol was added to the molybdenum solution in a separating funnel and shaken for some time. This solution was allowed to stand for some time, the colored complex formed was moved to the organic phase and no trace of color was left into the aqueous phase. The organic phase was separated out and passed through a small filter paper to remove any suspended water droplet. Then the absorption spectrum was measured by using $1 \mathrm{~cm}$ cell with reference to a blank solution containing all the reagents except molybdenum. This complex shows maximum absorption at $470 \mathrm{~nm}$ $(\lambda \max )$

Different dilutions of the standard were prepared by weighing the respective quantities of the said compound. The dilutions used were $0 \%, 10 \%, 20 \%, 30 \%, 40 \%$ and $50 \%$ which gave absorbance $0.066,0.158,0.251$, $0.344,0.445$ and 0.55 respectively. The ore sample was prepared for spectrophotometric determination of molybdenum using the standard procedure. The

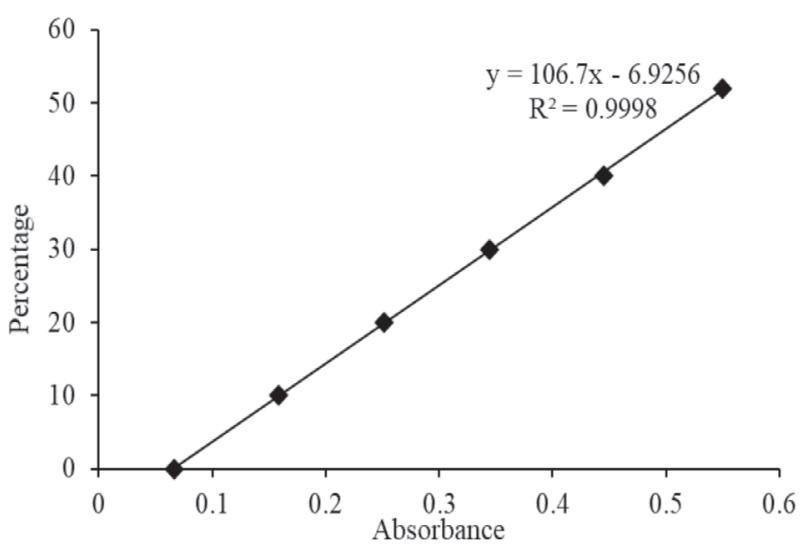

Fig. 1. UV analysis for percentage of Molybdenum. 
assignment was made based on the earlier reported work [12, 27-33].

The absorption spectra of ore complex were recorded at $470 \mathrm{~nm}$ which was found to be 0.370 . This absorbance value was computed with the factor value $106.7 x-6.9256$ (Fig. 1). After computing, the percentage of molybdenum in the ore sample was calculated which was found to be $31.2 \%$. The sample was prepared for spectrophotometric determination of percentage of molybdenum by using the standard procedure. The absorption of extracted ammonium molybdate was recorded at $470 \mathrm{~nm}$ which was found to be 0.315 . This absorbance value was computed with the factor value $=106.7 \mathrm{x}-6.9256$ (obtained from Fig 1). After computing, the percentage of molybdenum in the extracted sample was calculated which was found to be $26 \%$.

\section{Conclusions}

It has been concluded that mineral chemistry is one of the most important and useful tools for the extraction of different types of minerals. In this project, the molybdenum has been recovered to its useful form as ammonium molybdate using heat energy. The project is also very valuable because the extraction process is very simple and cost effective as compared to the previously reported. The spectroscopic analysis data revealed that the extraction yield was more than $83 \%$. This is manifested by $26 \%$ extraction in the form of ammonium molybdate from molybdenite containing $31.2 \%$ molybdenum.

\section{Conflict of Interest}

The authors declare no conflicts of interest.

\section{References}

1. LI Y., YANG S.H., TANG C.B., CHEN Y.M., HE J., TANG M.T. Reductive-sulfurizing smelting treatment of smelter slag for copper and cobalt recovery. J. Min. Metall. Sect. B. Metall. 54 (1), 73, 2018.

2. WANG Y., WANG L., YU J., CHOU K. Kinetics of carbothermic reduction of synthetic chromite. J. Min. Metall. Sect. B. Metall. 50 (1), 15, 2014.

3. HAN Z., WAN D., TIAN H., HE W., WANG Z., LIU Q. Pollution Assessment of Heavy Metals in Soils and Plants around a Molybdenum Mine in Central China. Pol. J. Environ. Stud. 28 (1), 123, 2019.

4. ĆURKOVIĆ M., SIPOS L., PUNTARIĆ D., DODIGĆURKOVIĆ K., PIVAC N., KRALIK K. Arsenic, Copper, Molybdenum, and Selenium Exposure through Drinking Water in Rural Eastern Croatia. Pol. J. Environ. Stud. 25 (3), 981, 2016.

5. HUANG X., LV X., SONG J., BAI C., ZHANG R., ZHOU $M$. Contact angle of water on iron ore fines: Measurement and analysis. J. Min. Metall. Sect. B. Metall. 51 (1), 33, 2015.
6. ATES A., DEMIREL H., MERGUL N. Risk Assessment and Chemical Fractionation of Heavy Metals by BCR Sequential Extraction in Soil of the Sapanca Lake Basin, Turkey. Pol. J. Environ. Stud. 29 (2), 1523, 2020.

7. MA L., XIA P., LIN T., HUANG X., TANG X. Speciation and Ecological Risks of Cobalt and Antimony in BlackNecked Crane $(<i>$ Grus nigricollis $</ i>)$ Habitat Sediments in China's Caohai Lake. Pol. J. Environ. Stud. 29 (2), 1725, 2020.

8. AWWAD A.M., AMER M.W., SALEM N.M., ABDEEN A.O. Green synthesis of zinc oxide nanoparticles ( $\mathrm{ZnO}-\mathrm{NPs})$ using Ailanthus altissima fruit extracts and antibacterial activity. Chem. Int. 6 (3), 151, 2020.

9. AWWAD A.M., SALEM N.M., AQARBEH M.M., ABDULAZIZ F.M. Green synthesis, characterization of silver sulfide nanoparticles and antibacterial activity evaluation. Chem. Int. 6 (1), 42, 2020.

10. GEBREKIDAN M., REDI-ABSHIRO M., CHANDRAVANSHI B.S., ELE E., MOHAMMED A.M., MAMO H. Influence of altitudes of coffee plants on the alkaloids contents of green coffee beans. Chem. Int. 5 (4), $247,2019$.

11. IGWE O., NWAMEZIE F. Green synthesis of iron nanoparticles using flower extract of Piliostigma thonningii and antibacterial activity evaluation. Chem. Int. 4, 60, 2018.

12. PERVAIZ M., BUTT K.M., RAZA M.A., RASHEED A., AHMAD S., ADNAN A., IQBAL M. Extraction and applications of aluminum hydroxide from bauxite for commercial consumption. Chem. Int. 1 (2), 99, 2015.

13. WANG H., LI G., FAKHRI A. Fabrication and structural of the $\mathrm{Ag}_{2} \mathrm{~S}-\mathrm{MgO} /$ graphene oxide nanocomposites with high photocatalysis and antimicrobial activities. J. Photochem. Photobiol. B: Biol. 111882, 2020.

14. LU M., CUI Y., ZHAO S., FAKHRI A. $\mathrm{Cr}_{2} \mathrm{O}_{3}$ /cellulose hybrid nanocomposites with unique properties: Facile synthesis, photocatalytic, bactericidal and antioxidant application. J. Photochem. Photobiol. B: Biol. 111842, 2020.

15. FAKHRI A., FEIZBAKHSH A., KONOZ E., NIAZI A. Facile Synthesis and Characterization of $\mathrm{CoS}_{2}-\mathrm{SiO}_{2} /$ Chitosan: The Photocatalysis in Real Samples, and Antimicrobial Evaluation. J. Inorg. Organomet. Polym. Mater. 29 (4), 1119, 2019.

16. FAKHRI A., FEIZBAKHSH A., KONOZ E., NIAZI A. Evaluation of photocatalytic performance for novel $\mathrm{Cr}_{2} \mathrm{~S}_{3}$ $\mathrm{SiO}_{2}$ nano-catalyst: optimization, quenching, antimicrobial studies. Mater. Res. Exp. 6 (10), 105909, 2019.

17. BABARINDE A., ONYIAOCHA G.O. Equilibrium sorption of divalent metal ions onto groundnut (Arachis hypogaea) shell: kinetics, isotherm and thermodynamics. Chem. Int. 2 (3), 37, 2016.

18. SRIVASTAVA S., PRAJAPATI D. Kinetic and thermodynamic study of Os (VIII) catalysed oxidation of glycine by ferrate (VI) in alkaline medium. Chem. Int. 3 (1), 31, 2017.

19. SRIKANTH V., SHYAMALA P., RAO K.S. Kinetic of oxidation of methyl orange by vanadium (V) under conditions VO2 and decavanadates coexist: Catalysis by Triton X-100 micellar medium. Chem. Int. 3 (1), 39, 2017.

20. WANG G., FAKHRI A. Preparation of CuS/polyvinyl alcohol-chitosan nanocomposites with photocatalysis activity and antibacterial behavior against $\mathrm{G}+/ \mathrm{G}-$ bacteria. Int. J. Biol. Macromol. 155, 36, 2020.

21. ASHRAF M.A., YANG Y., FAKHRI A. Synthesis of $\mathrm{NiS}-\mathrm{MoO}_{3}$ nanocomposites and decorated on graphene 
oxides for heterogeneous photocatalysis, antibacterial and antioxidant activities. Ceram. Int. 46 (6), 8379, 2020.

22. WANG L., WANG Q., LI J., CHOU K. Dissolution mechanism of $\mathrm{Al}_{2} \mathrm{O}_{3}$ in refining slags containing $\mathrm{Ce}_{2} \mathrm{O}_{3}$. J. Min. Metall. Sect. B. Metall. 52 (1), 35, 2016.

23. KANARI N, MENAD N, DIOT F, ALLAIN E, YVON J. Phosphate valorization by dry chlorination route. J. Min. Metall. Sect. B. Metall. 52 (1), 17, 2016.

24. KANARI N., MISHRA D., FILIPPOV L., DIOT F., MOCHÓN J., ALLAIN E. Kinetics of hematite chlorination with $\mathrm{Cl}_{2}$ and $\mathrm{Cl}_{2}+\mathrm{O}_{2}$ : Part I. Chlorination with Cl2. Thermochim. Acta 497 (1-2), 52, 2010.

25. TANG Z.-D., GAO P., HAN Y.-X., GUO W. Fluidized bed roasting technology in iron ores dressing in china - a review on equipment development and application prospect. J. Min. Metall. Sect. B. Metall. 55 (3), 295, 2019.

26. PIROSKOVA J., TRPCEVSKA J., ORAC D., LAUBERTOVA M., HORVATHOVA H., HOLKOVA B. Production of zinc oxide from hazardous waste - Sal Ammoniac Skimming. J. Min. Metall. Sect. B. Metall. 54 (3), 377, 2018.

27. JABEEN S., ALI S., NADEEM M., ARIF K., QURESHI N., SHAR G.A., SOOMRO G.A., IQBAL M., NAZIR A., SIDDIQUA U.H. Statistical Modeling for the Extraction of Dye from Natural Source and Industrial Applications. Pol. J. Environ. Stud. 28 (4), 2145, 2019.
28. HAMILTON-AMACHREE A., IROHA N.B. Corrosion inhibition of API 5L X80 pipeline steel in acidic environment using aqueous extract of Thevetia peruviana. Chem. Int. 6 (3), 110, 2020.

29. ALKHERRAZ A.M., ALI A.K., ELSHERIF K.M. Removal of $\mathrm{Pb}$ (II), $\mathrm{Zn}$ (II), $\mathrm{Cu}$ (II) and Cd (II) from aqueous solutions by adsorption onto olive branches activated carbon: Equilibrium and thermodynamic studies. Chem. Int. 6 (1), 11, 2020.

30. ALASADI M., KHAILI F.I., AWWAD A.M. Adsorption of $\mathrm{Cu}(\mathrm{II}), \mathrm{Ni}(\mathrm{II})$ and $\mathrm{Zn}(\mathrm{II})$ ions by nano kaolinite: Thermodynamics and kinetics studies. Chem. Int. 5 (4), 258, 2019.

31. SIDDIQUE A., HASSAN A., KHAN S.R., INAYAT A., NAZIR A., IQBAL M. Appraisal of heavy metals and nutrients from phosphate rocks, Khyber Pakhtunkhwa, Pakistan. Chem. Int. 4 (1), 1, 2018.

32. AYOFE N.A., OLADOYE P.O., JEGEDE D.O. Extraction and quantification of phthalates in plastic coca-cola soft drinks using high performance liquid chromatography (HPLC). Chem. Int. 4 (2), 85, 2018.

33. ELVIA R., CAHYANA A.H., WIBOWO W. Catalytic acetylation of $(+)$-cedrol with heterogeneous catalyst $\mathrm{H}_{2} \mathrm{SO}_{4} / \mathrm{SiO}_{2}$ under solvent free conditions. Chem. Int. 1 (4), 196, 2015. 